\title{
The Process of Adapting Children to the New Linguistic and Cultural Environment
}

\author{
Elvira Küün \\ Narva Colledge of the University of Tartu, Narva, Estonia
}

\begin{abstract}
The European Union (EU) promotes the use of multiple languages and the themes of multiple languages and multiple cultures in Estonia and other EU member states. The Estonian public curriculum (the National Curriculum for Basic Schools 2010; the National Curriculum for Upper Secondary Schools 2010) contains important elements in the context of multiculturalism. Consequently, the goal of this report is to provide an overview of possible cultural and language-related obstructions between students, as well as between students and teachers in basic schools with multicultural classes. An additional topic is strategies to overcome such problems in those classes. The main goal is to present these problems in order to publish more widely the Estonian experience with teaching new immigrant students. As the research method, unstructured in-depth interviews were used.
\end{abstract}

Keywords: immigration, multicultural classes, strategies to overcome, teaching methods, Estonian language, other languages

\section{Introduction}

Multiculturalism and worldwide globalisation mean that immigrants from other countries have also reached Estonia. In general, only in the recent 10 years has a significant amount of immigrants come to Estonia and this has created a challenge for Estonian educational system. In addition to developing an understanding of the host country's cultural aspects, the linguistic aspect and the development of language skills are also extremely important after arrival in the destination country. Looking at Estonia, the native language of children coming to Estonia differs from that of lessons in schools. The flexibility and fast reaction of teachers to the problem of offering a differentiated curriculum is much more important here. Another very important aspect is the financial possibilities that the state provides to train the teachers and to support the learning of students. The extent of new immigrants coming to Estonia is not yet high, but it cannot be presumed that the situation will not change in the future. And when it does, the state should develop certain founded decisions concerning the education policy. Law amendments may also become necessary from time to time.

Tallinn Lilleküla Upper Secondary School is actually the school in Estonia with the highest number of immigrant students, compared to other schools in the entire Estonia. The first new migrant students started attending this school in 2003. The most migrant students go to schools in Tallinn, which is also understandable because Tallinn has always been a multinational city and there are generally more opportunities to find a job there as well (cf. Helemäe, Plotkin, Semjonov, \& Vöörmann, 2000). The reasons to immigrate to Estonia

Elvira Küün, M.A., Assistant in Estonian Language, Division of Estonian Language and Literature, Narva Colledge of the University of Tartu. 
are varied and not all new immigrants plan to stay there for long. Some wish to travel on from Estonia to West Europe but some, looking for a temporary or permanent job or in certain cases also an asylum, wish to connect their future to Estonia. The analysis in this report can help make conclusions for Estonia's education policy.

\section{Theoretical Grounds}

Today, cultural exchange and adaptation to the destination country and its at-first unknown language and cultural environment are becoming more and more important, thanks to better mobility and the opening of national borders. The school has several roles in that. Besides its academic functions, the school is also an instrument of socialisation, establishing the prerequisites for fitting into the society (Küün, 2011). For most foreign children and young people, the school and other educational institutions are the main place where acculturation and communication between groups take place (Vedder \& Horenczyk, 2006). Acculturation is an important concept in the context of communication between different groups in a society. This concept is based on the assimilation of cultural elements and the nearing of different groups and nationalities in the course of contact (Viikberg, 1999, p. 18). The school takes on an important role in the adaptation of foreign children. It must change the requirements as well as the learning environment in order to satisfy the students' needs (Department for Education and Employment [DfEE], 1999). Teaching methods are very important, but so is support from the class (both the teacher and the students) as it helps with the adaptation process. $\S 21(5)$ of the Estonian Education Act states that a school is obligated to organise studies of the language and culture of a minority if the parents of at least 10 students with the same native language or communication language express a wish to that effect (Estonian Parliament, 2010a). Also, pursuant to § 27(1) of Estonian Education Act, a school is obligated to accept everyone subject to compulsory school attendance and the choice of specific school is related to one's place of residence (Estonian Parliament, 2010a). In addition to standard schools where both Estonian and Russian are used for studies (sometimes there are even separate sections with Russian and Estonian speaking studies in the same school), parents who recently arrived in Estonia can put their children in Tallinn Lilleküla Upper Secondary School where an international curriculum in English is taught or in Tartu International School where Estonian curriculum is taught but English is used as the study language (Kikas, 2010; Kook, 2012). In two schools, basic education is also provided in Finnish (the Finnish School in the capital of city Tallinn and the Finnish School in Tartu) (Kikas, 2010; Kook, 2012). The biggest problem for Estonian schools is their little experience with foreign children (Integration and Migration Foundation, 2015). Luckily, teachers are offered training for working with foreign children. This way they can prepare themselves for working with multicultural and multilanguage classes. Estonian government has also supported the publication of various learning aids for teachers teaching the children of new immigrants, for the students themselves, and for their parents. Constant attention must be paid to the publication of new learning aids in the future. The indicators showing that this field is up-to-date are actively established competence centres, as well as individual trainings for teachers and the establishing of a separate curriculum.

\section{Materials and Methods}

The purpose of this report is to analyse the specifics of linguistic and cultural adaptation from the institutional (the school) and the individual point of view, the latter being based on the assessments of foreign students and their teachers. Tallinn Lilleküla Upper Secondary School was chosen as an example where foreign and Estonian children learn together. Unstructured in-depth interviews were used as a research method. 
Participation in the research was voluntary and anonymous. The parents had to provide written consent that their child can participate in the research. It was necessary to visit the school two times in April 2015. First, the answers given by the headmaster are provided in order to understand the teaching background of the school.

\section{Results}

An interview with the deputy headmistress indicated that both the immigrants and the foreign students in Tallinn Lilleküla Upper Secondary School are taught according to the national curriculum. If there is a need, they are taught according to an individual curriculum. No fixed number of learning hours is established for new immigrants. Individual curricula foresee an intensive course of Estonian as a second language at first (up to 10 lessons per week). Due to that, they cannot attend all subject lessons as they would exceed the maximum allowed study load otherwise. According to the deputy headmistress, there are no subjects that new immigrants are not required to attend at the start of their education. In subsequent years, the number of language lessons is gradually reduced and the students participate more in regular subject lessons. She stressed that Estonian is taught by language immersion. She said, "It would be more correct to say that they gradually start to participate in all subject lessons as soon as possible." Estonian as a second language is taught for up to three years. Individual characteristics are taken into account when teaching and assessing the students' language skills. Every student is assessed individually and decisions are made on an individual basis. It became apparent from the interview that Estonian legislation promotes the successful studies of the children of new immigrants. The legislation has even been amended (individual curricula and special requirements in exams) and the students can take their exams in their native language (if there are interpreter services or that language available in Estonia). Additionally, the financial means provided per student are larger in the case of new immigrant students, in order to be able to give the additional Estonian lessons. Therefore, the extent of the state's support can be considered sufficient, at least on example of Tallinn Lilleküla Upper Secondary School. The deputy headmistress of Tallinn Lilleküla Upper Secondary School mentioned that due to the foreign linguistic and cultural environment, the new immigrant students are mostly in an emotionally difficult situation, but her opinion is that they largely cope well. Much is also dependent on the mental abilities and interests of the students. In the school examined, the biggest challenge is considered to be the preparation of lesson schedules; the students attend different classes and a schedule suitable for all of them is especially difficult to prepare. Moreover, the subject teachers need help and such help was also available in that school, but now the finances are insufficient for that. This person supported the students after the school by helping them do their homework and sometimes accompanied them to classes. The academic assessment of new immigrant students in Tallinn Lilleküla Upper Secondary School is organised as follows: In the first year, no grades are given to them; thereafter, their grades are given according to the system foreseen in the individual curriculum. In the first year, oral assessment takes place. In final exams, both new immigrant students and students from foreign schools are offered support. It was found that instead of the state exam of Estonian language, new immigrant students can take an exam of Estonian as a second language or an exam prepared by the school. The mathematics exam can also be translated to the student's native language. Exams are subject to the same special requirements as the individual curricula. In order to answer the questions of what is the most time-consuming and complicated aspect of the studies of new immigrants, whether any culture-related problems have been encountered, and how the eventual problems were solved, interviews were also held with the mathematics teacher (M) of Tallinn Lilleküla Upper Secondary School. She teaches new immigrant students since 2009. 


\section{The Joys and Worries of a Subject Teacher in School}

The mathematics teacher's experience shows that the environment is the most important factor influencing the speed of learning the language. If the environment, i.e., the school is positively minded and the child is also supported by the family, then the adaptation to the new cultural and linguistic environment is easier. The interview with the mathematics teacher indicated that she treated both new immigrants and foreigners in the same manner concerning the teaching methods. She has also used a dictionary in class to be forthcoming to the new immigrants and to use their native language.

M: For instance, when I taught Italian children, the Estonian children also learned numbers in Italian and the new immigrant children learned numbers in Estonian. Children corrected each other on their own.

She has also very frequently used the method of connecting words to pictures.

M: Once, when three different native languages were used in the class (Lithuanian, Irish, and Brazilian Portuguese), I explained everything to the smartest child who then passed the explanation on.

The fact that the teacher involved other students in the teaching process is remarkable. Such a method has a developing effect on both the student who teaches something and the students who are explained the subject by someone their age. The teacher utilised some methods developed on her own when teaching new immigrants, as well as textbooks and other conventional learning aids. This means combining her self-developed learning aids with those foreseen in the standard curriculum. It is naturally well understandable that a teacher has to work harder when having to teach new immigrants after a relatively short time while they do not speak the native language. On the other hand, it is an enriching experience for the teachers as they can acquire new experiences and use more creativity in their work; it is after all their goal to transfer knowledge to the students. Concerning the level of difficulty of the subject of mathematics, the teacher said that mathematics is a relatively universal subject; numbers are a universal and cross-border concept.

M: The work in a mathematics class is quite ordinary. Mathematics is picked up from day one. Difficulties occur in subjects where narration is needed, like natural sciences, geography, and history.

To the question of what is usually the easiest for new immigrants at the beginning of the lessons, the respondent replied that nothing is easy at the beginning.

M: They need to concentrate on many things at once: a new country, a new language, a new people, a new school, and a new school system. Some will never get used to it.

The responses indicate that for some children, the adaptation to the new linguistic and cultural environment, in this case the Estonian school environment, is not easy. Unfortunately, not all children adapt to the school. Luckily, possible problems resulting from different cultural backgrounds (e.g., behaviour, discipline, and beliefs hindering the lessons) have not occurred in the work of the interviewed mathematics teacher. According to her, the students make an effort of their own to understand everything and to not lag behind others in the class. Still, simultaneous teaching of both new immigrant students and Estonian students in the same classroom is a challenge for the teacher. The teacher must be able to work with everyone at once, regardless of their native languages and must make all efforts to make sure that all students in the class will understand the lessons, also by preparing additional learning aids, sometimes translating those and making clever use of teaching methods. 


\section{Educational Needs of the New Immigrants}

In order to find out the educational needs of the new immigrant students of Tallinn Lilleküla Upper Secondary School, some students from this category were also interviewed. The student respondents were one girl (G1) and three boys (B1, B2, and B3). The goal was to find out how well the respondents cope in the school in their own opinion, what had been the most difficult for them, and how they have solved those difficulties. It was also asked what was the easiest for them in the school. The interviewed students had come to Estonia for various reasons. All respondents started their studies in Tallinn Lilleküla Upper Secondary School a couple of years ago, with the exception of one respondent who had come to Estonia already in 2010. The interviewed students had come from various countries: Yemen (G1), Russia (B1), Sri Lanka (B2), and Iceland (B3). Except for one respondent (B1) who had come from Sri Lanka, the respondents had been living in Estonia since 2013; the boy from Sri Lanka had done so since 2010, having also attended an Estonian kindergarten for one year before the school. The respondent B2 from Sri Lanka had lived not only in Sri Lanka, but also in China and Turkey at young age. The respondent had the command of Tamil, Estonian, and English. All four students attended different hobby classes, for example, fencing, volleyball, and model airplanes. The importance of hobby classes cannot be understated for the children's personality development, their socialisation, adaptation to the new host country, or their faster learning of Estonian as the country's official language. Additionally, it provides the children with joy, valuable conversations, and an opportunity to find friends of their age and to communicate with them. None of the interviewed students used the help of a home teacher; instead, their mothers or sisters helped them with their homework. The students were also asked about their most difficult problems in the school. Different problems were mentioned: some of them concerning the teaching staff, and some the relationships with other students. Respondents G1 and B2 said that they have no worries in relation to the school. Still, a couple of the interviewed students had certain worries about the school: "I do not like physical education" (B1) and "When the teacher says 'Shut up' and when my bag is hidden away" (B3). Often, the fear of physical education classes was not related to the classes as a whole but instead to a certain level of bad physical form, sometimes even causing fear of attending the physical education classes. The replies of another respondent indicated that relationships with other students were not at their best. But as it became clear from the interview with the deputy headmistress, conflicts occasionally occur both between the new immigrants and Estonian children as well as among Estonian students themselves. It is presumed that group relationships are settled in that way, especially at the beginning when a new student appears. The fact that a teacher sometimes reprimands a student can be due to the situation where a new immigrant student is in class for a narrative-style subject and does not understand everything, becomes bored and in order to fill the gap, starts chatting with a desk mate.

The students were also asked about their greatest school joy. The replies were very varied again. The help of others was mentioned (for example, by the same boy who answered to the previous question that he did not like when his bag was hidden away, so he nevertheless has a support network at school); also, friends were mentioned several times, making the school days brighter for the new immigrants. Actually, an extra question was asked: Whether they have Estonian friends. All respondents without exception said that they have friends among Estonians. The respondents also spoke about the easiest subjects for them at school, for example, G1 and B1 mentioned Estonian as a second language. For the third child, the easiest subject was mathematics. He said that he had liked this subject since the 1st grade. The fourth respondent also said that Estonian as a second 
language is indeed the easiest subject for him but also mentioned several other subjects. B3 mentioned Estonian as a second language, robotics, arts, handicrafts for boys, and sometimes physical education. As the study's goal was to find out the extent of difficulties experienced by new immigrant students in a school with Estonian as the study language, the respondents were naturally also asked about the subjects that they found the most difficult. The replies were very original again: "English is difficult" (G1), "Physical education for me" (B1), "Estonian as a first language" (B2), and "History, Estonian as a first language, and natural sciences" (B3). As it can be seen, the selection of the most difficult subjects is also prevalently individual among the respondents. These replies indicate difficulties with indeed those subjects where narration is used, as the hindering factor is the students' as-yet insufficient command of Estonian. But the better their Estonian skills become over time, the easier and more comprehensible the narrative subjects should also become for them. The children were also asked about opportunities to learn their original language and culture outside their home, e.g., in a Sunday school. Unfortunately, all respondents said that they had no such opportunities. So, the promotion and development of their original culture and language is fully put on the families' shoulders. It would be useful for the maintenance of the original language if it were used actively in the family, so that those language skills will not be forgotten over time (see also Moon, Ben-Peretz, \& Brown, 2000, p. 772).

\section{Discussion and Conclusion}

The state provides financial support for the studies of new immigrant students having lived in Estonia for less than three years. For example, schools with Russian study language in Estonia are not paid extra for students, because those schools already have an intensive programme for learning Estonian. With new immigrants, the method of learning in pairs or small groups is used more often than in ordinary studies. Another difference between the ordinary students and the new immigrants is that the teachers often have to do double work, writing and speaking simultaneously because as a rule, reading is easier than listening for new immigrants. Body language, gestures, and facial expressions are also used, especially at the beginning when the child cannot speak Estonian yet. Moreover, non-verbal and verbal strategies are integrated when teaching Estonian. Undoubtedly, the mental capacity of the students also has a great role and their aptitude at the subjects is important as well. Among all subjects, the new immigrant students needed the least help with subjects related to talents. Mathematics was also mentioned because numbers are a universal concept and the students feel themselves as equals to others right from the beginning; this is a good basis for eager learning. Also, the new immigrants have more difficulties with narrative subjects, while doing better in arts or other talent-related subjects, as well as in mathematics, Estonian as a second language, and also English.

The most important is that the children should experience success in the classes and feel emotionally secure at the same time. Still, it is understandable that further generalisations about the linguistic adaptation of students of foreign origin in Estonian schools cannot be made on the basis of just six interviews. Therefore, this subject should be discussed more in depth in future studies. This can be done by, e.g., increasing the group of respondents, comparing the education in various regions of Estonia, and making comparative conclusions on that basis. Still, the results of this research are also a good example of the collection of information about children of foreign origin, as the in-depth interviews have provided a good opportunity for that. The adaptation, studies and coping of children of foreign origin in schools should be researched more in depth, because it is a topic of increasing relevance. 


\section{References}

Commission of the European Communities. (2005). Communication from the Commission to the Council, the European Parliament, the Economic and Social Committee and the Committee of the Regions-A new framework strategy for multilingualism. Retrieved November 29, 2014, from http://ec.europa.eu/education/policies/lang/doc/com596_en.pdf

Department for Education and Employment (DfEE). (1999). The national curriculum key stages 1 \& 2. London, U.K.: DfEE and QCA.

Estonian Parliament. (2010a). Republic of Estonia education act. Retrieved March 30, 2014, from https://www.riigiteataja.ee/akt/ 968165

Estonian Parliament. (2010b). The national curriculum for basic schools. Retrieved February 25, 2014, from https://www. riigiteataja.ee

Estonian Parliament. (2010c). The national curriculum for upper secondary schools. Retrieved February 29, 2014, from https://www.riigiteataja.ee

Goldenberg, C., Rueda, R. S., \& August, D. (2006). Socio-cultural influences on the literacy development. In D. August, \& T. Shanahan (Eds.), Developing literacy in second-language learners: Report of the National Literacy Panel on language-minority children and youth (pp. 319-340). Mahwah, N.J.: Lawrence Erlbaum Associates

Helemäe, L., Plotkin, A., Semjonov, F., \& Vöörmann, R. (2000). Identiteedi kujunemise probleemid post-sotsialistlikus keskkonnas (Identity formation problems in post-socialist environment). Tallinn: Inimõiguste Teabekeskus.

Integration and Migration Foundation. (2015). New immigrant child. Retrieved May 11, 2014, from http://www.meis.ee/uusimmigrant laste-haridus

Kikas, A. (2010). Kui kooli tulev laps on pärit teistsugusest kultuuriruumist (When a child is coming from the school of a different cultural space). Retrieved November 29, 2013, from http://www.teretere.eu

Kook, M. (2012). Välismaalt tulnud õpilaste keeleline kohanemine Tallinna Lilleküla Gümnaasiumi näitel (Language adoption of children from foreign countries based on Tallinn Lilleküla Upper Secondary School) (Bachelor's thesis, Tartu University).

Küün, E. (2011). Minority languages in Estonian segregative language environments. Journal of Estonian and Finno-Ugric Linguistics, 2(1), 223-241.

Moon, B., Ben-Peretz, M., \& Brown, S. (Eds.). (2000). The Routledge companion to education. London, U.K.: Routledge.

Rannut, Ü. (2005). Keelekeskkonna mõju vene õpilaste eesti keele omandamisele ja integratsioonile Eestis (Impact of language environment on Russian students upon Estonian language acquisition and integration in Estonia). Tallinn: Tallinn University Press.

Vedder, P. H., \& Horenczyk, G. (2006). Acculturation and the school. In D. L. Sam, \& J. W. Berry (Eds.), The Cambridge handbook of acculturation psychology (pp. 419-438). New York, N.Y.: Cambridge University Press.

Viikberg, J. (1999). Akulturatsioon (Acculturation). In J. Viikberg (Ed.), Eesti rahvaste raamat (Book of nations of Estonia). Tallinn: Estonian Encyclopaedia Publishers. 